\title{
Strategic Orientation, Environmental Management Systems, and Eco-Innovation: Investigating the Moderating Effects of Absorptive Capacity
}

\author{
Chin-Hung Tseng ${ }^{1, *}$, Kuo-Hsiung Chang ${ }^{2}$ and Ho-Wen Chen ${ }^{1}$ \\ 1 Department of Environmental Science and Engineering, Tunghai University, No.1727, Sec.4, \\ Taiwan Boulevard, Xitun District, Taichung 40704, Taiwan; Hwchen@thu.edu.tw \\ 2 Department of International Business, Tunghai University, No.1727, Sec.4, Taiwan Boulevard, Xitun District, \\ Taichung 40704, Taiwan; Kuo1@thu.edu.tw \\ * Correspondence: Kevin12291@gmail.com; Tel.: +886-4-2631-4516 or +886-0935-375-102
}

Citation: Tseng, C.-H.; Chang, K.-H.; Chen, H.-W. Strategic Orientation,

Environmental Management Systems, and Eco-Innovation: Investigating the Moderating Effects of Absorptive Capacity. Sustainability 2021, 13, 12147. https://doi.org/10.3390/ su132112147

Academic Editor: Roberto Cerchione

Received: 17 September 2021

Accepted: 28 October 2021

Published: 3 November 2021

Publisher's Note: MDPI stays neutral with regard to jurisdictional claims in published maps and institutional affiliations.

Copyright: (c) 2021 by the authors. Licensee MDPI, Basel, Switzerland. This article is an open access article distributed under the terms and conditions of the Creative Commons Attribution (CC BY) license (https:// creativecommons.org/licenses/by/ $4.0 /)$.

\begin{abstract}
Environmental management studies have proposed that firms can achieve substantial cost advantages over competitors and enhance their competitive positions by implementing an environmental management system (EMS). This study further investigates strategic orientation (customer, competitor, and innovation orientation) and focuses on the effect of strategic orientation on EMSs and eco-innovation; it also examines the mediating role of EMSs in the relationship between strategic orientation and eco-innovation. Furthermore, this study investigates the moderating role of absorptive capacity in the relationship between strategic orientation and EMSs. Reliability and validity analyses of a sample of 142 respondents indicated that the study design was effective, consistent, and reliable. The findings indicate that (1) strategic orientation (competitor and innovation orientation) positively influences EMSs, (2) EMSs positively influence eco-innovation, (3) absorptive capacity-enhancing strategic orientation positively influences EMSs, and (4) EMS intermediary strategic orientation positively influences eco-innovation. This study contributes to the theoretical understanding of why some firms exhibit greater proactivity in EMSs than others do.
\end{abstract}

Keywords: strategic orientation; customer orientation; competitor orientation; innovation orientation; environmental management system (EMS); eco-innovation; absorptive capacity

\section{Introduction}

Global warming and ozone depletion have been recognized as global environmental issues [1,2]. The concept of corporate environmental protection has become more and more important in the academic and commercial fields [3,4]. An example is ISO 14001, that is, an environmental management system (EMS). This system is primarily designed to overcome environmental problems and provide appropriate management and corresponding strategies for managing such problems. ISO 14001 certification can help businesses of all sizes to make their daily operations more sustainable. Not only can they meet the requirements of laws and regulations, but they can also meet the requirements of customers. Recent research focuses on explaining the adoption of environmental management practices such as ISO 14001 [5].

In this study, we define EMSs as structured approaches to planning and implementing eco-innovation measures [6] and integrating environmental and ecological management into the company's daily operations, long-term planning, and other quality management systems [7,8]. Companies implement EMSs, that is, through raw material input, waste management, energy consumption, environmental impact reversal, and improvement of public image to save costs $[9,10]$. According to environmental management literature, companies can improve their economic benefits and environmental performance by managing the process of implementing EMSs [11,12]. EMSs can also assist companies in developing 
a comprehensive approach to enhance their competitive advantage, and because of that, they allow companies to operate sustainably [13].

This article contributes to the literature in three ways. First, it discusses the impact of strategic orientation on EMSs. Strategic orientation includes three dimensions: customer orientation, competitor orientation, and innovation orientation. Customer orientation is the extent of taking customers as the protagonist, creating and maintaining relationships with customers [14], and getting timely feedback from them. Customer needs change rapidly. Being customer-oriented makes the strategy more effective in recognizing these changes and guides companies to invest necessary resources to formulate corresponding new products or services, reconnect the production process of corporate management, and provide flexible product lines to meet the changing preferences of customers [14]. Competitor orientation is to supervise and compare the behaviors of competitors, let the business departments understand their relative position in the market, evaluate their strengths and weaknesses, and respond effectively to the strategies of competitors, which is beneficial to the business's department insights $[15,16]$. Innovation orientation refers to the discourse that promotes openness to new ideas, reflecting the willingness of enterprises to adopt and implement new technologies, skills, resources, and management systems as a strategic direction $[17,18]$. Therefore, this study believes that corporate strategic orientation will positively influence EMSs through customer orientation, competitor orientation, and innovation orientation, so I want to explore the influence between strategic orientation and EMSs. Studies have reported that strategic orientations (i.e., customer, competitor, and innovation orientation) are conducive to the development of EMSs.

Second, we discuss the mediating role of EMSs in the relationship between strategic orientation and eco-innovation. Although there is a broad consensus on the value of EMSs, few people know why some companies adopt EMSs more proactively than others, and under what conditions companies adopt EMSs. This study adopts the company's resource-based view (RBV) to understand active EMSs and ecological innovation [19-24]. Christmann [25] believes that the implementation of an environmental management system directly enhances the competitive advantage of business operations. Previous studies have applied RBV to environmental management strategy analysis [3,26-30].

Third, we discuss the moderating role of absorptive capacity in the relationship between strategic orientation and EMSs. This study believes that whether the knowledge accumulation ability of EMSs can be converted into useful knowledge for the enterprise should be related to the corresponding strategic orientation of the enterprise itself; for companies with better strategic orientation, with the accumulation of strategic orientation knowledge, the company will have more abilities to absorb, transform, and integrate internally and externally, and thus structure a more appropriate EMS. This further promotes EMS ideas among enterprises, and after new ideas are conceptualized, more specific concepts are formed, and then they are integrated into the corporate culture through reflection and review; then, explicit knowledge is formed, and the knowledge is actually applied during work to promote the generation of ecological innovation behavior.

\section{Theory, Conceptual Framework, and Hypotheses Development}

\subsection{How Strategic Orientation Affects EMSS}

Companies must provide a series of strategic orientations to assist various departments in moving towards established management goals. Strategic orientations can enhance the company's potential for competition and contribute to corporate performance growth. Firms will be able to enhance their competitive advantage from implementing "best practices" of environmental management [25]. Strategy-oriented implementation, as well as the process of strategy implementation, allows companies to review their own capabilities at any time to respond to this turbulent market, which has become even more important. In particular, the variability of customer preferences and expectations is coordinated with the management goals set by the company, and unique action plans are developed [31-34]. When an enterprise effectively responds to the needs of the internal and external environ- 
ment and integrates relevant resources with each other under consistent conditions, the enterprise will achieve superior and sustained performance [35].

\subsection{How Absorptive Capacity Affects the Implementation of EMSs}

Cohen and Levinthal [36] mentioned that absorptive capacity refers to whether an enterprise has the ability to generate new knowledge, defining it as the ability of a company to recognize, transform, and use external knowledge. The ability of an enterprise to develop new knowledge externally depends on its own learning ability, that is, its ability to acquire, create, and disseminate new knowledge, and its ability to absorb positively affects its ability to integrate [37]. Absorptive capacity refers to the ability of an enterprise to recognize and acquire external knowledge [38], including the synergistic effect of corporate learning, innovation, and combination capabilities on competitors [39]; it is also an enterprise's identification and assimilation of and potential to use external knowledge [40]. Day [41] proposed that enterprises can achieve market orientation by emphasizing learning, and thus they can continuously improve market information processing activities. Therefore, if a company has a keen ability to absorb and uses EMSs maturely, the addition of this capability will help change the face of corporate competition, and the demand for companies will continue to increase, update, re-allocate, and recreate their resources and capabilities to be in line with market competitiveness. Furthermore, it can enhance and combine existing capabilities and improve management system knowledge and systems themselves.

\subsection{How EMSs Affect Eco-Innovation}

According to the resource-based view (RBV), extended dynamic capability research not only focuses on the company's resources itself, but also focuses on the company's ability to create new resources or modify existing resources to meet the sustainability of its resource capabilities [42]. Judge and Douglas [43] proposed that companies that successfully incorporate natural environmental management issues into their strategy-oriented process can gain a competitive advantage. It is believed that the company's resources lead to the ability to influence the company's performance, and then the dynamic ability to promote the company's decision-making. This study investigated the influence of internal organizational culture on the implementation of EMSs [19-22]. Porter and van der Linde [44] pointed out that in order to compete in a turbulent market, companies must continue to innovate and improve their operational capabilities through the control of efficiency and cost in order to gain a competitive advantage and stabilize the competitiveness of the company.

\subsection{Strategic Orientation Cultures and EMSs}

Strategic orientation is the guiding principle that influences corporate marketing and strategy formulation activities $[34,45,46]$. They reflect the company's strategic orientation to create valuable behaviors of excellent performance [16] and to establish deep-rooted values and beliefs in the company through business [47]. To keep the scope of the study manageable, I consider three types of strategic orientation subsets: customer orientation, competitor orientation, and innovation orientation $[16,18,48]$.

Customer orientation refers to the collection of intelligence about customers to satisfy their needs and desires [49-51]. Narver and Slater [52] argue that customer orientation is a firm's sufficient understanding of its target buyers in order to be able to create superior value for them. As Han et al. [17] stated, customer orientation advocates a continuous, proactive disposition toward meeting customers' expressed and latent needs.

According to Kohli and Jaworski [53], competitor orientation refers to a firm's ability to identify, analyze, and respond to competitors' actions. Narver and Slater [52] argue that competitor orientation reflects a seller's ability to understand the short-term strengths and weaknesses and long-term capabilities and strategies of both the key current and the key potential competitors. 
Innovation orientation refers to a new idea that promotes openness, reflecting the company's willingness to adopt and implement new technologies, resources, skills, and management systems through change [18]. Porter and van der Linde [54] mentioned that innovation in the production process and technical management process can significantly help to reduce costs and improve operational efficiency. Taking the form of a price war due to fierce market competition may hinder the company's willingness to invest in innovation; on the contrary, they may decide to imitate the innovation of their competitors to reduce production costs.

Customer orientation cultures make the supplier more proactive, as this orientation responds to international buyer needs [55]. Therefore, customer orientation cultures are likely to play a major role regarding the proactive EMS [56]. Competitor orientation culture emphasizes identifying, analyzing, and responding to competitors' actions. Therefore, suppliers that have to imitate competitors' cultures tend to pursue proactive EMSs. Imitating competitors' new services can be regarded as an attractive source of service innovation, leading to minimizing risks and development costs. Firms operating in a highly dynamic market are active in pursuing proactive EMSs to enhance their competitive advantage.

We believe that in the long run, companies can gain significant benefits in competitive markets by encouraging innovation orientation, promoting open ideas for new things, and adopting innovative behaviors, mainly in improving the quality of the products they provide to customers and improving the efficiency of their value chain activities. Innovation orientation emphasizes the tendency to pursue proactive EMSs, which includes sharing new ideas, solving problems, and innovative responses [16,17].

With customer-oriented values, firms excel in creating and maintaining bonds with customers and obtain timely feedback from them. When customer needs change rapidly, customer orientation enables firms to recognize those changes and guides them to invest necessary resources, to develop appropriate new products or services, to refine production processes, and to offer a flexible product line to cater to customers' changing preferences [14]. As a result, customer-oriented firms can adapt to market changes effectively.

Hypothesis 1 (H1). Strategic orientation cultures (a. customer orientation, b. competitor orientation, and c. innovation orientation) have a positive impact on proactive EMSs.

\subsection{The Moderating Role of Absorptive Capacity}

To advance the understanding of the impacts of organizational cultures on EMS, we explore the contingency role of absorptive capacity. Over the past two decades, the literature of strategic orientation cultures has neglected the absorptive capacity. In this study, absorbing ability positively affects the ability to integrate [34]; absorptive ability refers to the ability of an enterprise to identify external knowledge and obtain the ability to absorb [35]. The ability to absorb includes the synergistic effect of corporate learning, innovation, and combination capabilities on competitors [36]; it is also the potential for companies to identify, assimilate, and use external knowledge [37].

Drucker [57] believes that external knowledge will affect the company's R\&D personnel's development direction for new products, pointing out that external knowledge allows companies to explore knowledge and processes that help meet specific needs. Tripsas [35] believes that absorbing ability is the ability of an enterprise to acquire and transform external knowledge; absorbing ability uses the most common external knowledge such as identification, acquisition, assimilation, development, application, transformation, etc., while the value of ability and acquisition of external knowledge are a kind of potential absorption capacity [37]. Through competitor spillover knowledge, business operators can imitate competitors and strengthen EMSs to attack competitors' competitive disadvantages through absorbing ability, even using product differentiation to eliminate competitors' competitive advantages.

Second, Chesbrough [58], Gassmann et al. [59] pointed out that the source of enterprise innovation does not necessarily come from within the enterprise. It can also be 
integrated and transformed with existing internal EMS resources through technology transfer, outsourcing R\&D, and joint development. This application and other methods obtain technology and knowledge that are more different from the market, thereby expanding the development of new products. Therefore, if a company has a keen ability to absorb and uses EMSs maturely, the addition of this capability will help change the face of corporate competition. The demand will continue for companies to increase, update, re-allocate, and recreate their resources and capabilities to be in line with market competitiveness; companies can enhance and combine existing capabilities and improve management system knowledge and systems.

Third, absorptive capacity is a form of special resources. The RBV approach has highlighted the importance of resources. According to the RBV [22], a firm outperforms its competitors if it manages its overall resources so that they generate capabilities that are rare, not substitutable, valuable, and difficult to imitate. Resources give the firm the opportunity to grow in choosing the best strategy in response to external requirements [60] and are critical determinants of knowledge creation [61]. Therefore, special resources are likely to moderate the relationship between strategic orientation cultures and proactive EMSs. Thus, we posit the following hypothesis:

Hypothesis 2 (H2). Absorptive capacity positively moderates the relationship between strategic orientation cultures (a. customer orientation, b. competitor orientation, and c. innovation orientation) and EMSs in such a way that the relationship will be stronger in suppliers with absorptive capacity than in firms with no absorptive capacity.

\subsection{EMSs and Eco-Innovation}

The main reason eco-innovation is selected as the dependent variable is that EMSs are proposed to create a competitive advantage. This study employs the resource-based view (RBV) of the firm $[19-24,47]$ to address the relationships between proactive EMSs and competitiveness (eco-innovation).

Porter and van der Linde [44] argued that pollution is a form of economic waste. As Hart [3] predicted, due to increasing awareness of the constraints imposed by pollution, prevention will increasingly be a source of competitive advantage. Eco-innovation results from the efficiency of production processes and reducing waste disposal costs $[3,61-63]$ that include redesigning production processes to be less polluting and using energy-saving manufacturing processes [44,64].

Proactive EMSs can be expected to enhance eco-innovation in two ways. First, addressing environmental problems earlier than competitors will allow suppliers to gain cost advantage through learning curve effects [65-69]. Second, addressing environmental problems early and developing solutions to environmental challenges can influence the future development of environmental regulations. Therefore, by addressing environmental problems early and influencing environmental regulations, the suppliers can not only raise their rivals' costs [70], but also gain a relative eco-innovation advantage. Thus,

Hypothesis 3 (H3). The EMS is positively associated with eco-innovation.

\subsection{Conceptual Framework}

Figure 1 shows our proposed conceptual framework. 


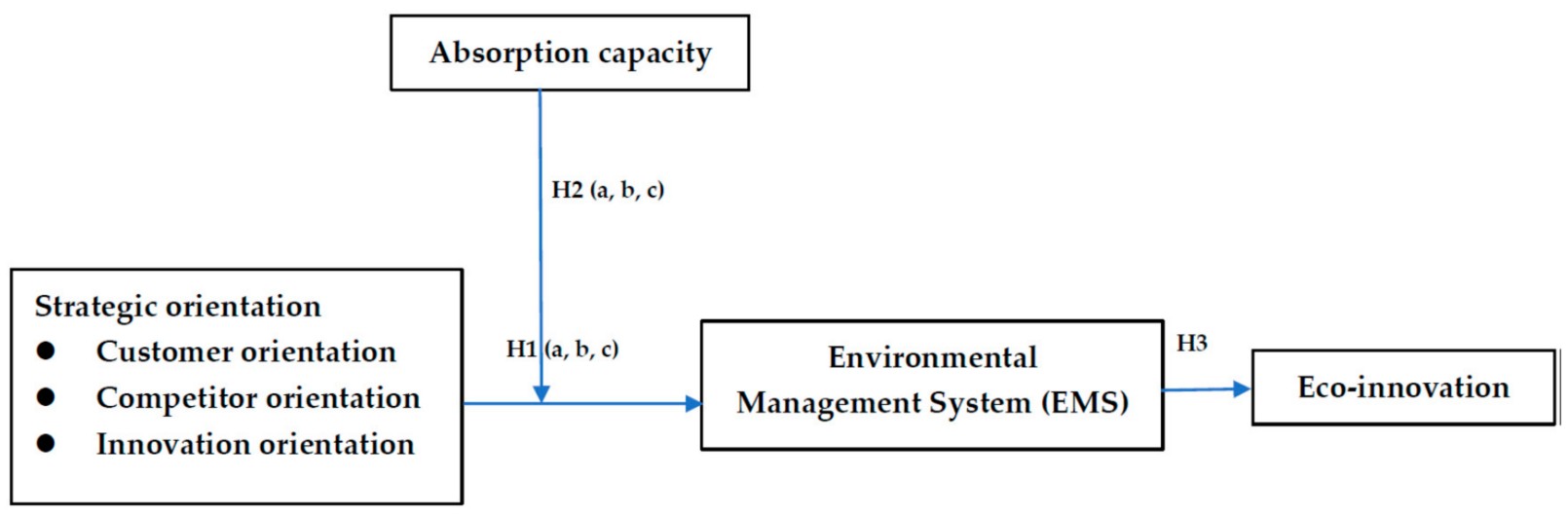

Figure 1. Conceptual framework of EMS.

\section{Methods}

\subsection{Sample and Sampling Procedure}

The sampling frame was constructed from Taichung Industrial Park and the Central Science Park, where there are factories and manufacturing industries that are engaged in ISO 14001 management. We investigated firms operating in Taiwan because of the intense pressure such firms face when seeking ISO 14001 environmental management standards certification and the emphasis on environmental management in the Taiwanese government's economic development agenda. The unit of analysis used was the relationship between Taiwanese suppliers and their buyers. We obtained a list of firms from a commercial provider to limit the target population of this study to firms that engage in eco-innovation. From the 500 contacts on the list, we received 162 responses, yielding a response rate of $32.4 \%$. We excluded 20 responses because of considerable missing data on the main variables. The final sample consisted of 142 usable questionnaires.

Following Armstrong and Overton's [71] procedure to assess nonresponse bias, we compared the key variables from a sample of firms that responded early with those from sample of firms that responded late. We discovered no significant differences in variables such as number of employees and sales volume between early and late respondents. Thus, nonresponse bias should not significantly affect the study results. The respondents had served at their respective firms for an average of 12.5 years. The average age of these supplier firms was 19.5 years. Employee numbers varied between 100 and 20,500, but $49.3 \%$ of suppliers had fewer than 100 employees. The duration of relationships with buyers ranged from 5 to 30 years, but $55.6 \%$ of suppliers maintained such links for more than 15 years.

\subsection{Measures}

\subsubsection{Construct Measurement}

Venkatraman [72] and Narver and Slater [52] have defined strategy orientation as the means and the business model, especially the unit-level strategy, adopted by an enterprise to achieve its goal. Strategy orientation is comprised of three main concepts: customer orientation, competitor orientation, and innovation orientation. Absorptive capacity was measured using four items adapted from studies by Minbeava et al. [73] and Van den Hooff and Van Weenen (2004). Eco-innovation was measured using three items adapted from a study by Aragón-Correa [74].

We controlled for several potential sources of heterogeneity. The size and age of a firm and the length of a buyer-supplier relationship are likely to affect EMSs. We measured firm size as the logarithm of the number of employees and firm age as the number of years of operation since a firm's establishment. Finally, we controlled for length of relationship by using the logarithm of the number of years duration of a buyer-supplier relationship. 


\subsubsection{Reliability and Validity}

Confirmatory factor analysis was conducted in Amos 24.0 to assess the reliability and the convergent and discriminant validity of the multi-item scales [75]. Because the samples were small, we created two measurement models: one for EMSs and eco-innovation and one for strategic orientation and absorptive capacity. Although the chi-square statistic was significant, it is sensitive to the sample size and model complexity [76]. These indices are more appropriate for assessing model fit. The results for indicator loadings were significant $(p<0.001)$. Additionally, we estimated composite reliability (CR) to determine the internal consistency of the measures. The CR of each factor ranged from 0.85 to 0.92 $(>0.7)$. The Cronbach's alpha for each construct was above the widely accepted threshold of 0.7. Appendix A provides details on the constructs and their operationalization. The indicator loadings were significant, indicating convergent validity.

The discriminant validity of the measures was assessed. We tested whether, for each pair of constructs, the squared correlation between the two constructs was less than the average variance extracted (AVE) for each construct [77]. The AVE for each construct exceeded 0.5, the squared correlations of that construct with all others in the model [76].

\subsubsection{Common Method Bias}

We also assessed whether common method bias posed a serious threat. Following Podsakoff et al. [78], we adopted Harman's one-factor test and entered all the principal constructs into a principal component factor analysis. No common factor loading was apparent for any of the measures, and Factor 1 accounted for roughly $18 \%$ of the variance in the data [78]. Therefore, common method bias was not considered a serious problem for our data.

\section{Results}

The correlation coefficients of the variables are summarized in Table 1. According to the SPSS correlation analysis, the correlation coefficients among competitor orientation, innovation orientation, and EMS implementation were significant $(p<0.001)$; customer orientation, competitor orientation, innovation orientation, and EMS implementation were respectively related to the eco-innovation. The correlation coefficients between innovation variables were all significant $(p<0.001)$, and the correlation coefficients of customer orientation, competitor orientation, innovation orientation, and absorptive capacity with EMS implementation were significant $(p<0.001)$.

Table 1. Descriptive statistics and correlations.

\begin{tabular}{ccccccccc}
\hline & Avg. & S.D. & $\mathbf{1}$ & $\mathbf{2}$ & $\mathbf{3}$ & $\mathbf{4}$ & $\mathbf{5}$ & $\mathbf{6}$ \\
\hline Customer orientation & 6.114 & 0.746 & & & & & & \\
Competitor orientation & 5.278 & 0.978 & $0.451^{* * *}$ & $(0.85)$ & & & & \\
Innovation orientation & 5.814 & 0.925 & $0.527^{* * *}$ & $0.355^{* * *}$ & $(0.84)$ & & \\
EMS & 5.362 & 1.004 & $0.285^{* * *}$ & $0.401^{* * *}$ & $0.348^{* * *}$ & $(0.71)$ & \\
Absorptive capacity & 5.735 & 0.953 & $0.500^{* * *}$ & $0.273^{* * *}$ & $0.670^{* * *}$ & $0.221^{* *}$ & $(0.92)$ & \\
Eco-innovation & 4.773 & 1.287 & $0.251^{* *}$ & 0.100 & $0.420^{* * *}$ & $0.352^{* * *}$ & $0.425^{* * *}$ & $(0.94)$ \\
\hline
\end{tabular}

${ }^{*}$ Correlation is significant at the 0.05 level (two-tailed). ${ }^{* *}$ Correlation is significant at the 0.01 level (two-tailed). ${ }^{* * *}$ Correlation is significant at the 0.001 level (two-tailed).

Cronbach's alpha for each construct was above the widely accepted threshold of 0.7.

The results are shown in Table 1. The Cronbach's alpha for each aspect was higher than 0.7 , and the factor loadings were all significant; therefore, the model had sufficient convergent validity.

Table 1 presents the means, standard deviations, reliability (coefficient alphas), and correlations of the variables. We analyzed these data through hierarchical regression analysis. Table 2 shows the hierarchical regression results for three models in which the dependent variable is EMS implementation and only the control variables are included. 
Among the control variables, relationship length exerted a positive and significant effect on EMS implementation. We hypothesized that strategy orientation would have a positive effect on EMS implementation. In Model 1, competitor orientation significantly and positively affected proactive EMS implementation $(b=0.54, p<0.001)$, supporting $\mathrm{H} 1 \mathrm{~b}$, as did innovation orientation $(b=0.22, p<0.01)$. However, customer orientation did not exert any significant positive effect on EMS $(b=0.04, p>0.1)$. Therefore, our results support H1b and H1c.

Table 2. Regression results for EMS (strategic orientation and EMS).

\begin{tabular}{cc}
\hline & $\begin{array}{c}\text { Model 1 (H1-H3) } \\
\text { (EMS) }\end{array}$ \\
\hline Firm size & $-0.07(-1.03)$ \\
Firm age & $-0.06(-0.78)$ \\
Relationship length & $-0.05(-0.68)$ \\
Customer orientation & $0.04(0.45)$ \\
Competitor orientation & $0.54^{* * *}(6.61)$ \\
Innovation orientation & $0.22^{* *}(2.64)$ \\
$\mathrm{R}^{2}$ & 0.54 \\
Adjusted $\mathrm{R}^{2}$ & 0.52 \\
F value & $26.07^{* * *}$ \\
Max VIFs & 2.29 \\
\hline
\end{tabular}

** $p<0.01, * * * p<0.001$.

As Table 3 shows, the impact of EMS implementation on the relationship between customer orientation and ecological innovation $(\beta=0.23, T=3.13, p<0.01)$ declined to ( $\beta=0.51, T=6.74, p<0.001)$. EMS implementation fully mediated the relationship between competitor orientation and ecological innovation $(\beta=0.11, T=1.21)$, which decreased to ( $\beta=0.56, T=6.17, p<0.001)$. Therefore, $\mathrm{H} 3$ was supported.

Table 3. Regression results for eco-innovation (strategic orientation, EMS and eco-innovation).

\begin{tabular}{|c|c|c|c|c|}
\hline & Model 2 & Model 3 & Model 4 & Model 5 \\
\hline & \multicolumn{4}{|c|}{ (Eco-innovation) } \\
\hline Firm size & $-0.07(-0.94)$ & $-0.11(-1.47)$ & $-0.14(-1.80)$ & $-0.01(-0.16)$ \\
\hline Firm age & $-0.05(-0.64)$ & $-1.11(-1.21)$ & $-0.11(-1.21)$ & $-0.04(-0.48)$ \\
\hline $\begin{array}{l}\text { Relationship } \\
\text { length }\end{array}$ & $0.18 *(2.24)$ & $0.17(1.84)$ & $0.17(1.84)$ & $0.09(0.99)$ \\
\hline EMS & $0.64^{* * *}(9.76)$ & & & \\
\hline $\begin{array}{l}\text { Customer } \\
\text { orientation }\end{array}$ & & $0.51 * * *(7.05)$ & & \\
\hline $\begin{array}{l}\text { Competitor } \\
\text { orientation }\end{array}$ & & & $0.50^{* * *}(6.82)$ & \\
\hline $\begin{array}{l}\text { Innovation } \\
\text { orientation }\end{array}$ & & & & $0.60^{* * *}(8.53)$ \\
\hline $\mathrm{R}^{2}$ & 0.44 & 0.30 & 0.29 & 0.38 \\
\hline Adjusted $\mathrm{R}^{2}$ & 0.42 & 0.28 & 0.27 & 0.36 \\
\hline F value & $26.49^{* * *}$ & $14.55^{* * *}$ & $13.74^{* * *}$ & $20.60^{* * *}$ \\
\hline Max VIFs & 1.63 & 1.64 & 1.64 & 1.67 \\
\hline
\end{tabular}

${ }^{*} p<0.05,{ }^{* * *} p<0.001$.

Table 4 indicates that absorptive capacity could strengthen customer orientation, with significant explanatory power $(\beta=0.26, T=3.40, p<0.01)$ that decreased to $(\beta=0.46$, $T=4.87, p<0.001)$. Absorptive capacity could strengthen competitor orientation and exhibited significant explanatory moderating power $(\beta=0.16, T=2.74, p<0.01)$, which decreased to $(\beta=0.56, T=7.97, p<0.001)$. With absorptive capacity to strengthen the innovation orientation results, the model reached significant explanatory power $(\beta=0.26$, $T=3.52, p<0.01)$ and decreased to $(\beta=0.48, T=4.39, p<0.001)$. 
Table 4. Regression results for EMS (absorptive capability added, strategic orientation and EMS).

\begin{tabular}{cccc}
\hline & Model 6 & Model 7 & Model 8 \\
\hline Firm size & $-0.08(-1.16)$ & $-0.09(-1.39)$ & $-0.17(-0.22)$ \\
Firm age & $0.00(-0.00)$ & $-0.08(-1.05)$ & $-0.17(-0.19)$ \\
Relationship length & $-0.04(-0.49)$ & $-0.04(-0.55)$ & $-0.07(-0.83)$ \\
Absorptive Capability (AC) & $0.31^{* *}(3.51)$ & $0.24^{* *}(3.32)$ & $0.28^{* *}(2.67)$ \\
Customer orientation (CUO) & $0.46^{* * *}(4.87)$ & & \\
CUO X AC & $0.26^{* *}(3.40)$ & & \\
Competitor orientation (COO) & & $0.56^{* * *}(7.97)$ & \\
COO X AC & & $0.16^{* *}(2.74)$ & $0.48^{* * *}(4.39)$ \\
Innovation orientation (IO) & & & $0.26^{* *}(3.52)$ \\
IO X AC & 0.42 & 0.55 & 0.41 \\
R & 0.39 & 0.53 & 0.39 \\
Adjusted R & $16.06^{* * *}$ & $27.73^{* * *}$ & $15.79 * *$ \\
F value & 2.08 & 1.66 & 2.75 \\
Max VIFs & &
\end{tabular}

** $p<0.01,{ }^{* * *} p<0.001$.

Therefore, the regression analysis results were significant and thus supported H2a, $\mathrm{H} 2 \mathrm{~b}$, and $\mathrm{H} 2 \mathrm{c}$.

\section{Conclusions and Discussion}

This study proposed a conceptual framework in which a proactive EMS in the context of high absorptive capability permits strategic orientation, which in turn is associated with greater competitive advantage (in eco-innovation). We investigated whether (a) strategic orientation influences the likelihood of having an EMS and (b) whether an EMS is associated with a competitive advantage (in eco-innovation).

\subsection{Theoretical Implications}

The purpose of this study is to examine the impact of strategic orientation (customer orientation, competitor orientation, innovation orientation) on an environmental management system (EMS) and eco-innovation, while also examining the mediating role of EMSs in the relationship between strategic orientation and eco-innovation. This study enriches the theoretical understanding in several ways. First, it provides insights into the impact of strategic orientation on EMS implementation. The results suggest that competitor orientation and innovation orientation are the main factors affecting proactive EMS implementation. Additionally, customer orientation does not influence EMS implementation. Competitor orientation and innovation orientation enable suppliers to collect intelligence about competitors. Thus, competitor orientation enables suppliers to acquire the information that is required for long-term competition strategies and for approaches to environmental management that are preferred by buyers [52].

Absorptive capacity positively moderates the relationship between strategic orientation and EMSs. Thus, strategic orientation (external resource) and absorptive capability (internal resource) complement each other in their influence on EMS implementation. These results augment the strategic orientation literature by explaining why customer and competitor orientation can be antithetical. In addition, absorptive capacity negatively influences the relationship between customer orientation and EMS implementation. Such a result indicates that strong absorptive capacity mainly acts as a substitute to promote EMS implementation. Overall, competitor orientation (external resource) and absorptive capacity complement each other in their effects on EMS implementation, but customer orientation (external resource) and absorptive capacity act as substitutes in their influence on EMS implementation.

Finally, this research expands the literature by assessing whether a proactive EMS is conducive to eco-innovation. This study employed the RBV of the firm [19-22] to address the relationships between a proactive EMS and competitiveness (eco-innovation). 


\subsection{Managerial Implications}

This study also contributes empirical findings on firms in Taiwan. Little empirical evidence has demonstrated the effect of strategic orientation on proactive EMSs. We provide evidence of the different strategic orientations that influence companies and managers not only to ensure the authenticity of their environmental information, but also to legitimize their environmental management strategies and actions. Our findings support the validity of the interaction effect of strategic orientation cultures and absorptive capacity on EMS implementation. In the environmental management literature, a few studies have provided insight into how absorptive capacity may affect EMS implementation. Complementing these studies, we suggest that the interaction between strategic orientation and absorptive capacity encourages EMS implementation. Absorptive capacity, as an external resource, moderates the effects of strategic orientation.

Second, despite considerable academic and managerial interest in EMSs, little empirical research has investigated the determinants and consequences of EMSs. An unanswered question within organization and management research is how organizational culture determines why some firms have greater success with EMSs. Research adopting a more systematic perspective of EMSs by defining the many activities they encompass is thus required. Furthermore, most empirical works have been conducted in the United States. Consequently, managers of organizations in other countries can know little about the appropriateness and desirability of their EMSs $[79,80]$.

Third, managers should be aware that absorptive capacity may enhance the effect of competitor orientation on an EMS. In addition, managers should seek new methods for use in EMSs. Our results indicate that fostering absorptive capacity may help firms to enhance the relationship between competitor orientation and proactive environmental management.

\subsection{Limitations and Future Research}

Several limitations are worth addressing. First, the cross-sectional nature of our study precludes causal inference. However, EMS implementation seems to induce eco-innovation, and eco-innovation may also affect EMS implementation. Thus, although future research should adopt longitudinal designs to provide evidence of the direction of causality, we believe our results will not be invalidated.

Second, although we drew our sample from a variety of information technology firms in Taiwan, the generalization of these findings to other industries should be performed with caution. Third, we based our study on the subjective assessment of key informants; thus, the data regarding eco-innovation were susceptible to subjective biases. Future research that collects diverse and objective data can potentially overcome such biases.

Author Contributions: C.-H.T. and K.-H.C. designed the research, analyzed the data, and interpreted the results. H.-W.C. provided extensive suggestions throughout the study regarding the Introduction, Methods, Results, and Discussion sections. All authors have read and agreed to the published version of the manuscript.

Funding: This research received no external funding.

Institutional Review Board Statement: Not applicable.

Informed Consent Statement: Not applicable.

Data Availability Statement: Raw/processed data required to reproduce these findings cannot be shared at this time as the data also form part of an ongoing study.

Acknowledgments: The highest gratitude for this paper goes to Kuo-Hsiung Chang and Ho-Wen Chen for their careful guidance and teaching, from the selection of the thesis theme, the modification of the questionnaire items, and the way of writing the content to the completion of the entire thesis. I am grateful to both of them for their tireless enlightenment and correction, and I would like to extend my sincerest thanks to the two professors! 
Conflicts of Interest: The authors declare no conflict of interest.

\section{Appendix A}

\section{Measurement Items}

Constructs: Customer Orientation

(Narver, Slater, and MacLachlan, 2004) (Cronbach's alpha = 0.845; AVE = 0.54;

$\mathrm{CR}=0.852$

1. We attach great importance to improving customer satisfaction.

2. We continue to create new service content to provide customers with more value.

3. The basis of our competitive advantage is in fully understanding customer needs.

4. We formulate business strategies for the purpose of increasing customer value.

5 . We regularly evaluate customer satisfaction.

6. We attach great importance to, and continually improve the quality of, after-sales service.

7. Our customers attach great importance to environmental pollution prevention and management.

Constructs: Competitor Orientation

(Cronbach's alpha $=0.84 ; \mathrm{AVE}=0.54 ; \mathrm{CR}=0.854)$ [47]

1. Our employees can share information about competitors.

2. Our competitors have strengthened environmental pollution prevention and control management to enhance their own advantages.

3. Our competitors have developed favorable environmental management methods for the prevention and control of environmental pollution.

4. We can quickly respond to the actions of competitors.

5. The company's leaders often discuss the strategies of competitors.

6. The company's leaders are good at finding and seizing opportunities to establish a competitive advantage.

Constructs: Innovation Orientation

(Cronbach's alpha $=0.639 ; \mathrm{AVE}=0.52 ; \mathrm{CR}=0.652$ ) [47]

1 . The company welcomes innovative suggestions.

2. Company managers actively seek out innovative ideas.

3. Company employees put forward innovative ideas because, even if they fail to implement the ideas, they know they will not be punished for it.

4. The project manager actively supports innovative ideas, experiments, and creative processes.

5. Innovation is considered too risky, so it is often rejected by the company (reverse question).

Constructs: Environmental Management System

(ISO Publications, 2005) (Cronbach's alpha $=0.92 ; \mathrm{CR}=0.58 ; \mathrm{AVE}=0.928$ ) [25]

1. The company implements energy-saving measures.

2. The company practices the use of renewable resources.

3. The company recycles waste.

4. The company performs an environmental audit.

5 . The company promotes greening activities such as tree planting.

6. The company promotes environmental protection activities in the office.

7. The company organizes environmental protection education and training.

8. The company actively participates in community environmental protection activities. Constructs: Eco-Innovation

(Cronbach's alpha $=0.909 ; \mathrm{AVE}=0.72 ; \mathrm{CR}=0.912$ ) [18]

1. New environmental and sustainability information used by the company has surpassed existing market knowledge.

2. New environmental and sustainability information is used by the company to educate project team members about innovations in the market.

3. New concepts of environmental protection and sustainability used by the company are necessary for future market success.

4. New environmental and sustainability information used by the company can attract potential customers in the market in the future. 


\section{Measurement Items}

5. The company's product innovation is in line with environmental protection and 0.966 sustainability policies, which is highly novel for our industry.

6. The company's product innovation is environmentally friendly and sustainable and

0.966 surpasses existing standards in our industry.

7. The company's product innovation is environmentally friendly and sustainable, providing new ideas for our industry.

0.965

0.963

0.964

8. The company's product innovation is environmentally friendly and sustainable, with $\quad 0.968$

a high degree of creativity.

0.963

Constructs: Absorptive Capacity

(Cronbach's alpha $=0.918 ; \mathrm{AVE}=0.66 ; \mathrm{CR}=0.925)$ [37]

1. The company leaders have clearly defined the objectives of the environmental pollution prevention and control management plan.

2. The company leaders participate in the entire execution of the environmental pollution prevention and management plan.

3. The company leaders have a strong determination to implement environmental

4. The company leaders attach great importance to the opinions and suggestions of employees on the implementation of the environmental pollution prevention and control management plan.

5. The company leaders encourage the development of new product technologies or processes.

6. The company leaders encourage participation in major decisions regarding the environmental pollution prevention and control management plan.

\section{References}

1. Schmidheiny, S. Changing Course: A Global Business Perspective on the Environment; The MIT Press: Cambridge, MA, USA, 1992.

2. Smart, B. Beyond Compliance: A New Industry View of the Environment; World Resources Institute: Washington, DC, USA, 1992.

3. Shrivastava, P. Ecocentric management for industrial ecosystems: Management paradigm for a risk society. Acad. Manag. Rev. 1995, 20, 118-137. [CrossRef]

4. Hart, S.L. A natural-resource-based view of the firm. Acad. Manag. Rev. 1995, 20, 986-1014. [CrossRef]

5. Delmas, M.A.; Toffel, M.W. Organizational responses to environmental demands: Opening the black box. Strat. Manag. J. 2008, 29, 1027-1055. [CrossRef]

6. Poksinska, B.; Dahlgaard, J.J.; Eklund, J.A. Implementing ISO 14000 in Sweden: Motives, benefits and comparisons with ISO 9000. Int. J. Qual. Reliab. Manag. 2003, 20, 585-606. [CrossRef]

7. Zutshi, A.; Sohal, A. A study of the environmental management system (EMS) adoption process within Australasian organisations-2. Role of stakeholders. Technovation 2004, 24, 371-386. [CrossRef]

8. Burnett, R.D.; Hansen, D.R. Eco-efficiency: Defining a role for environmental development: A case study of GW power utilities. Int. J. Inf. Manag. 2007, 26, 339-348.

9. Briggs, S.L.K. Clarifying the Intent of ISO 14001, Quality Progress, Standards Outlook. Available online: http:/ / www.asq.org/ quality-progress /2007/08/environmental-management-and-sustainability/iso-14001-hits-10-year-mark.html (accessed on 5 October 2021).

10. Mori, Y.; Welch, E.W. The ISO 14001 environmental management standard in Japan: Results from a national survey of facilities in four industries. J. Environ. Plan. Manag. 2008, 51, 421-445. [CrossRef]

11. Ann, G.E.; Zailani, S.; Wahid, N.A. A study on the impact of environmental management system (EMS) certification towards firms' performance in Malaysia. Manag. Environ. Qual. Int. J. 2006, 17, 73-93. [CrossRef]

12. Fortunski, B. Does the environmental management standard ISO 14001 stimulate sustainable development? Manag. Environ. Qual. Int. J. 2008, 19, 204-212. [CrossRef]

13. Polsek, R.B. Quality toolbox: A framework for business sustainability. Environ. Qual. Manag. 2007, 17, 81-88.

14. Slater, S.F.; Narver, J.C. Customer-led and market-oriented: Let's not confuse the two. Strat. Manag. J. 1998, 19, 1001-1006. [CrossRef]

15. Gao, G.Y.; Zhou, K.Z.; Yim, C.K.Y. On what should firms focus in transitional economies? A study of the contingent value of strategic orientations in China. Int. J. Res. Mark. 2007, 24, 3-15. [CrossRef]

16. Gatignon, H.; Xuereb, J. Strategic orientation of the firm and new product performance. J. Mark. Res. 1997, 36, 77-90. [CrossRef]

17. Han, J.K.; Kim, N.; Srivastava, R.K. Market orientation and organizational performance: Is innovation a missing link? J. Mark. 1998, 62, 30-45. [CrossRef]

18. Hurley, R.F.; Hult, G.T.M. Innovation, market orientation, and organizational learning: An integration and empirical examination. J. Mark. 1998, 62, 42-54. [CrossRef] 
19. Wernerfelt, B. A resource-based view of the firm. Strat. Manag. J. 1984, 5, 171-180. [CrossRef]

20. Barney, J.B. Strategic factor markets: Expectations, luck, and business strategy. Manag. Sci. 1986, 32, 1231-1241. [CrossRef]

21. Barney, J. Firm resources and sustained competitive advantage. J. Manag. 1991, 17, 99-120. [CrossRef]

22. Barney, J.; Wright, M.; Ketchen, D., Jr. The resource-based view of the firm: Ten years after 1991. J. Manag. 2001, $27,625-641$. [CrossRef]

23. Dierickx, I.; Cool, K. Asset stock accumulation and the sustainability of competitive advantage: Reply. Manag. Sci. 1989, $35,1514$. [CrossRef]

24. Rumelt, R.P. How much does industry matter? Strat. Manag. J. 1991, 12, 167-185. [CrossRef]

25. Christmann, P. Effects of "best practices" of environmental management on cost advantage: The role of complementary assets. Acad. Manag. J. 2000, 43, 663-680. [CrossRef]

26. Russo, M.V.; Fouts, P.A. A resource-based perspective on corporate environmental performance and profitability. Acad. Manag. J. 1997, 40, 534-559. [CrossRef]

27. Maxwell, J.; Rothenberg, S.; Briscoe, F.; Marcus, A. Green schemes: Corporate environmental strategies and their implementation. Calif. Manag. Rev. 1997, 39, 118-134. [CrossRef]

28. Marcus, A.; Geffen, D. The dialectics of competency acquisition: Pollution prevention in electric generation. Strateg. Manag. J. 1998, 19, 1145-1168. [CrossRef]

29. Rugman, A.M.; Verbeke, A. Corporate strategies and environmental regulations: An organizing framework. Strateg. Manag. J. 1998, 19, 363-375. [CrossRef]

30. Sharma, S.; Vredenburg, H. Proactive corporate environmental strategy and the development of competitively valuable organizational capabilities. Strateg. Manag. J. 1998, 19, 729-754. [CrossRef]

31. Coyne, K.P. Sustainable competitive advantage-What it is, what it isn't. Bus. Horiz. 1986, 29, 54-61. [CrossRef]

32. Aragón-Sánchez, A.; Sánchez-Marín, G. Strategic orientation, management characteristics, and performance: A study of Spanish SMEs. J. Small Bus. Manag. 2005, 43, 287-308. [CrossRef]

33. Tseng, C.-H.; Chang, K.-H.; Chen, H.-W. Strategic orientation, environmental innovation capability, and environmental sustainability performance: The case of Taiwanese suppliers. Sustainability 2019, 11, 1127. [CrossRef]

34. Sroufe, R. Effects of environmental management systems on environmental management practices and operations. Prod. Oper. Manag. 2009, 12, 416-431. [CrossRef]

35. Venkatraman, N.; Prescott, J.E. Environment-strategy coalignment: An empirical test of its performance implications. Strat. Manag. J. 1990, 11, 1-23. [CrossRef]

36. Cohen, W.M.; Levinthal, D. Absorptive capacity: A new perspective on learning and innovation. Adm. Sci. Q. 1990, 35, 128. [CrossRef]

37. Grant, R.M. Prospering in dynamically-competitive environments: Organizational capability as knowledge integration. Organ. Sci. 1996, 7, 375-387. [CrossRef]

38. Tripsas, M. Surviving radical technological change through dynamic capability: Evidence from the typesetter industry. Ind. Corp. Chang. 1997, 6, 341-377. [CrossRef]

39. De Boer, M.; van den Bosch, F.A.; Volberda, H. Managing organizational knowledge integration in the emerging multimedia complex. J. Manag. Stud. 1999, 36, 379-398. [CrossRef]

40. Zahra, A.S.; George, G. Absorptive capacity: A review reconceptualization, and extension. Acad. Manag. Rev. 2002, 27, 185-203. [CrossRef]

41. Day, G.S. The capabilities of market-driven organizations. J. Mark. 1994, 58, 37-52. [CrossRef]

42. Grant, R.M. The resource-based theory of competitive advantage: Implications for strategy formulation. Calif. Manag. Rev. 1991, 33, 114-135. [CrossRef]

43. Judge, W.Q.; Douglas, T.J. Performance implications of incorporating natural environmental issues into the strategic planning process: An empirical assessment. J. Manag. Stud. 1998, 35, 241-262. [CrossRef]

44. Porter, M.E.; van der Linde, C. Green and competitive: Ending the stalemate. Harv. Bus. Rev. 1995, 73, $120-134$.

45. Noble, C.H.; Sinha, R.; Kumar, A. Market orientation and alternative strategic orientations: A longitudinal assessment of performance implications. J. Mark. 2002, 66, 25-39. [CrossRef]

46. Hertin, J.; Berkhout, F.; Wagner, M.; Tyteca, D. Are EMS environmentally effective? The link between environmental management systems and environmental performance in European companies. J. Environ. Plan. Manag. 2008, 51, 259-283. [CrossRef]

47. Carrillo-Hermosilla, J.; del Río, P.; Könnölä, T. Diversity of eco-innovations: Reflections from selected case studies. J. Clean. Prod. 2010, 18, 1073-1083. [CrossRef]

48. Voss, G.; Voss, Z. Strategic orientation and firm performance in an artistic environment. J. Mark. 2000, 64, 67-83. [CrossRef]

49. Day, G.S. Continuous learning about markets. Calif. Manage. Rev. 1994, 36, 9-31. [CrossRef]

50. Deshpandé, R.; Farley, J.U.; Webster, F.E., Jr. Corporate culture, customer orientation, and innovativeness in Japanese firms: A quadrad analysis. J. Mark. 1993, 57, 23-37. [CrossRef]

51. Hunt, S.D.; Morgan, R. The comparative advantage theory of competition. J. Mark. 1995, 59, 1-15. [CrossRef]

52. Narver, J.C.; Slater, S.F. The effect of a market orientation on business profitability. J. Mark. 1990, 54, 20-35. [CrossRef]

53. Kohli, A.K.; Jaworski, B.J. Market orientation: The construct, research propositions, and managerial implications. J. Mark. 1990, 54, 1-18. [CrossRef] 
54. Porter, M.E.; van der Linde, C. Toward a new conception of the environment-competitiveness relationship. J. Econ. Perspect. 1995, 9, 97-118. [CrossRef]

55. Calantone, R.J.; Kim, D.; Schmidt, J.B.; Cavusgil, S.T. The influence of internal and external firm factors on international product adaptation strategy and export performance: A three-country comparison. J. Bus. Res. 2006, 59, 176-185. [CrossRef]

56. Tantong, P.; Karande, K.; Nair, A.; Singhapakdi, A. The effect of product adaptation and market orientation on export performance: A survey of Thai managers. J. Mark. Theory Pr. 2010, 18, 155-170. [CrossRef]

57. Drucker, P.F. Innovation and Entrepreneurship: Practice and Principles; Big Apple Tuttle-Mori Literary Agency, Inc.: New York, NY, USA, 1985.

58. Chesbrough, H. Open Innovation; Harvard Business School Press: Boston, MA, USA, 2003.

59. Gassmann, O.; Reepmeyer, G.; von Zedtwitz, M. Leading Pharmaceutical Innovation, Trends and Drivers for Growth in the Pharmaceutical Industry; Springer: Cham, Switzerland, 2004.

60. Sharfman, M.P.; Wolf, G.; Chase, R.B.; Tansik, D.A. Antecedents of organizational slack. Acad. Manag. Rev. 1988, 13, 601-614. [CrossRef]

61. Makadok, R.; Barney, J.B. Strategic factor market intelligence: An application of information economics to strategy formulation and competitor intelligence. Manag. Sci. 2001, 47, 1621-1638. [CrossRef]

62. Shrivastava, P. Environmental technologies and competitive advantage. Strat. Manag. J. 1995, 16, 183-200. [CrossRef]

63. Stead, W.E.; Stead, J.G. Management for a Small Planet: Strategic Decision Making and the Environment; Sage Publications: Thousand Oaks, CA, USA, 1996.

64. Saeidi, S.P.; Sofian, S.; Saeidi, P.; Saeidi, S.P.; Saaeidi, S.A. How does corporate social responsibility contribute to firm financial performance? The mediating role of competitive advantage, reputation, and customer satisfaction. J. Bus. Res. 2015, 68, 341-350. [CrossRef]

65. Ashford, N.A. Understanding technological responses of industrial firms to environmental problems: Implication for government policy. In Environmental Strategies for Industry: International Perspectives on Research Needs and Policy Implications; Fischer, K., Schot, J., Eds.; Island Press: Washington, DC, USA, 1993; pp. 277-307.

66. Lieberman, M.B.; Montgomery, D.B. First-mover advantages. Strateg. Manag. J. 1988, 9, 41-58. [CrossRef]

67. Nehrt, C. Timing and intensity of environmental investments. Strateg. Manag. J. 1996, 17, 535-547. [CrossRef]

68. Halila, F.; Rundquist, J. The development and market success of eco-innovations. Eur. J. Innov. Manag. 2011, 14, 278-302. [CrossRef]

69. Roscoe, S.; Cousins, P.D.; Lamming, R.C. Developing eco-innovations: A three-stage typology of supply networks. J. Clean. Prod. 2016, 112, 1948-1959. [CrossRef]

70. Nehrt, C. Maintainability of first mover advantages when environmental regulations differ between countries. Acad. Manag. Rev. 1998, 23, 77-97. [CrossRef]

71. Armstrong, J.S.; Overton, T.S. Estimating nonresponse bias in mail surveys. J. Mark. Res. 1977, 14, 396. [CrossRef]

72. Salop, S.; Schefman, D. Raising rivals' costs. Am. Econ. Rev. 1983, 73, 267-271.

73. Minbaeva, D.; Pedersen, T.; Bjorkman, I.; Fey, C.F.; Park, H.J. MNC knowledge transfer, subsidiary absorptive capacity, and HRM. J. Int. Bus. Stud. 2003, 34, 586-599. [CrossRef]

74. Aragon-Correa, J.A. Strategic proactivity and firm approach to the natural environment. Acad. Manag. J. 1998, 41, 556-567. [CrossRef]

75. Arbuckle, J.; Wothke, W. AMOS 4 User's Reference Guide; Smallwaters Corporation: Chicago, IL, USA, 1999.

76. Bagozzi, R.P.; Yi, Y.; Phillips, L.W. Assessing construct validity in organizational research. Adm. Sci. Q. 1991, 36, 421. [CrossRef]

77. Fornell, C.; Larcker, D.F. Evaluating structural equation models with unobservable variables and measurement error. J. Mark. Res. 1981, 18, 39-50. [CrossRef]

78. Podsakoff, P.M.; MacKenzie, S.B.; Lee, J.Y.; Podsakoff, N.P. Common method biases in behavioral research: A critical review of the literature and recommended remedies. J. Appl. Psychol. 2003, 88, 879-903. [CrossRef]

79. Coglianese, C.; Nash, J. (Eds.) Regulating from the Inside: Can Environmental Management Systems Achieve Policy Goals? Resources for the Future: Washington, DC, USA, 2001.

80. Disterheft, A.; Caeiro, S.; Ramos, M.R.; Azeiteiro, U. Environmental management systems (EMS) implementation processes and practices in European higher education institutions-Top-down versus participatory approaches. J. Clean. Prod. 2012, 31, 80-90. [CrossRef] 